\title{
Borders by Proxy, Europe's Aggressive Border Restrictions and the Perils of Young African Migrants
}

\author{
Michael Onyedika Nwalutu \\ Social Justice Education, OISE, University of Toronto, Toronto, Canada \\ Email: michael.nwalutu@mail.utoronto.ca
}

Received 29 December 2014; accepted 20 February 2015; published 28 February 2015

Academic Editor: Felicia Ihuoma Nwalutu, University of Toronto, Canada

Copyright (C) 2015 by author and Scientific Research Publishing Inc.

This work is licensed under the Creative Commons Attribution International License (CC BY). http://creativecommons.org/licenses/by/4.0/

(c) (i) Open Access

\section{Abstract}

The intrinsic challenges in the intersection of international laws and codes of praxis with respect to the operation of EU states' border officials towards migrant individuals, to be specific, migrant African youth, is particularly pathetic and is a statement about the state's commitment and compliance to its obligation and to the tenets of universal human rights law. This paper uses secondary data analysis and anti-racist and anti-colonial theories to examine the currently troubling dynamics of youth's transnational border-crossing experiences. It concludes inter alia, that an understanding of the thought processes of potential migrants and their resolve to reach their goals at all cost might bring about a shift in the view of transnational migration stakeholders and scholars, and possibly chart a new trajectory, that might engender some modifications in existing policies for accommodation, and effective handling of the globally burgeoning cases of migrant individual.

\section{Keywords}

Borders, Migration, Youth, Transnational, Globalization, Racism, Colonization

\section{Introduction}

The intersection of the survivalist's ambitions of African migrant youth and the border-restriction operations of European Union authorities is becoming a predictable oxymoron. More so when insidious plague of racism combines with the political and socio-economic activities of the industrialized North to continue to perpetuate disruptions in the developing South (Simms, 2009; Chomsky, 2006; Willinsky, 1998), constituting citizens pre- 
viously settled and peaceful into stateless forced migrants (Nwalutu, 2014; Baxter, 2008; Chua, 2003). These forcefully displaced migrants, mainly youth from the global South are continuously faced with enormous restrictive rules designed to check their entry into receiving societies of the North. There is therefore an emerging concern on the impact of the heightened securitization of borders and intensification of selective migrant surveillance on the cultures of economic and political migration in countries of the industrialized North, specifically the EU states as it affects African migrant youth and the international freedom of movement.

\section{Author's Subjective Position}

As a Western-educated Nigerian-Canadian, it is still difficult to attempt to answer some of the questions surrounding why young adults like me would decide to leave our familiar environments of birth, ignoring the uncertainties of being an alien in a foreign country and migrating thousands of miles across transnational borders to find new abodes overseas. It is even more perplexing to realize that despite daily inundation with news of tragic ordeals of young Africans involved in migration across the international boundaries to Europe, more and more youth are ever ready to risk it to Oversea. Also the current global economic recession digging at the heels of most nations including European nations-means hostility from the citizens of these nations who would look on immigrants with suspicion-that they constitute strains on their nations dwindling resources (Kimon, 2009; Ngai, 2005; Li, 2003). I am therefore writing bestride two worlds-one in which academic, economic and socio-political privileges enjoyed by a few negates the right of other citizens enmeshed in bureaucratic bottlenecks and policy imperatives - and the other in which the limitations imposed on me by natural positioning in birth, political policies and material realities of the social environment conflate to redefine migrants identity and humanity. I am writing from the standpoint of epistemic saliency defined by George Sefa Dei (2011) as speaking from the authenticity of one's own experiences and voice. In other words, a space that allows a local subject to speak of his/her informed knowledge-base as distinct from being spoken for. It is the consciousness of my positioning in these two distinct worlds and inherent experiences which, constantly nudge me up to attempt to explore the ever-widening gap between the transnational migrants (specifically, migrant youth) and the receiving societies that informs my decision to explore in this work, the inherent contradictions of international laws and codes of practices with respect to the operation of EU states' border officials towards migrant individuals, especially migrant African youth. By so doing I hope to accentuate the duplicitous role of the EU states in the unsavory and often tragic migration experiences of African youth. Two questions will guide the thrust of this paper, which includes: how might transnational border restrictions serve as a pointer to the commitment of states to international humanitarian laws? How might we begin to reappraise transnational youth migrants positioning in the context of the global whole?

\section{Review of Literature}

The battle of border control is presently going far beyond the ambits of the nation state, to imagined territories. Against this backdrop, Bigo and Guild (2005) examines the link between the prevailing border securitization, penalization and incarceration as they affect Western countries and the new form of border controlling (policing from distance) or from delocalized borders to new social and imagined territory within and outside the territorial boundaries of the nation state. Elspeth Guild (2005) raises a critical question in his book contribution as he asks: “...who is entitled to move?” (p. 14). Guild notes that globalization is the positioning of economy-driven mobility above the authority of the nation state in which multi-national corporations secure passage across the barriers of transnational borders using their economic powers. Of import to my paper is Guild's recognition that: "The right to move for economic gain, whether in the form of goods, capital, service or persons, in a globalizing world is increasingly limited to those who are already economically advantaged” (p. 14). And I would add, to those deemed acceptable to the host nations. For instance, in Araujo (2014), the realization of another group of subordinate "Other" in more recent developments as opposed to the usual African migrants poses a serious problematization of conscience and re-evaluation of action to the immigration policy makers in Portugal. Until now, immigrants probably were the "illegal Africans", so dubbed by the nation state's coloniality of power and tropes of racism. But now, Brazilians and Ukrainians are part of the burgeoning migrant labor border-crashers in Portugal. The notion of cultural diversity in a supposedly homogenous Portugal thus became a concern for the critics of Portugal immigration policy. I argue therefore that accepting the narratives of globalization as a precursor for racism in immigration discourses in Portugal as elsewhere, subsumes neo-colonial projects into the 
dynamics of push and pull rationality, which apparently obscures the role of extant colonial projects that globalization represents. In contemporary constitution of race and debates on immigration in Portugal, as in other European countries, current influences and perpetuation of subjugation through colonial legacies are always occluded (Toasije, 2009). I argue that Araujo's (2014) use of post-colonial is both illogical and unrealistic because it is an assumption or outright denial of the presence of colonization in the current global socio-political processes. Neo-colonial subjugation is not just the persisting lived experiences of countries of developing South, but a continuously breeding, and mutating socio-political canker-worm. Therefore contemporary narrative on immigration and diversity in Portugal as in many Western states depoliticizes colonization through the logics of history and indigenous connections. This denial of colonization to establish a false link to interculturality, wittingly evades the racism concerns engendered by the presence of the migrant Other in the host society.

\section{EU Border Restriction and African Migrants through the Lenses of Anti-Colonial/Anti-Racist Discourses}

Racism is a preconceived process that derogatorily labels an individual or group for the purpose of segregation, marginalization, domination and imposition of hegemony by the dominant individual(s). It is an act of social representation and construction of difference aimed at positioning the dominant social group to enjoy certain exclusive privileges that are girded around by socio-political power imbalances and barricaded from the subordinate individual(s) with taboos of normativity. It is difficult to talk about race without looking into power relationships which is where the $19^{\text {th }}$ century Western colonization and present neo-colonial structures and processes play critical roles. Sefa Dei (2011) reasons that as anti-racists agents we must move to an inclusive race-based analysis of colonial relations with the understanding that representation is not only about subject identities and identifications but also about fundamental issues of economic, material and structural manifestations in existing human conditions. Antiracist theory therefore must aim to redress these fundamental issues. As an analytical approach anti-colonial framework is a perspective that challenges all manifestations of hegemony and imposition of ideas and practices of cultural and socio-political domination. In other words, any exercise of self-assertion or self-location is meaningful if it seeks to challenge or disrupt existing social dynamics of power imbalances.

Relating the discourses of anti-racism to the phenomenon of African youth's experiences at the transnational borders, particularly at the extended borders of the European Union, the realities of lopsided power relationship begins to emerge. The systems of border securitization and surveillance are designed to intercept and detain signifiers of racialized bodies or their representation. The taking up of such worded symbolisms as victims of traffickers, Illegal migrants, Clandestine and Boat-people are racist coinages of representation and markers of social difference at the borders of European Union. The disturbing reality of representation of difference is the positioning of the racialized individual(s) at the margins of social echelon. Spaces such as the transnational borders have the tendency to reproduce hegemony, dominance and privilege because such spaces also come with particular histories and readings. Therefore the experiences of the racialized bodies of African youth in European borders cannot be fully grasped in discourses of splits binaries of regular or irregular, legal and illegal migrants, because we are not unaware of the maxim that occupying certain spaces comes with meanings and politics. The racial positioning of whiteness at international borders implies that Europe wields an unlimited power to extend its authority of border surveillance to the North African sea ports of Libya, Tunisia, Algeria, Egypt and Morocco. These ports are patrolled by FRONTEX, an EU border security agency charged with keeping the unwanted vagrant bodies out of mainland Europe. One would be tempted to ask what complicit role the leaders of these African frontline states are playing to make EU aggressive border policies and praxis worthwhile. The answer is worst than imagined. Many young Africans have been brutally gunned-down at the borders of North Africa on passage to Europe (see Brachet, 2012; Baxter, 2008; Toasije, 2009). It is paradoxical however, that Europeans traveling to Africa do not face similar harassment, criminalization, restrictions detention and deportation African youth migrants suffer at the borders of Europe. Whiteness is a system and is also a property. There is therefore a politicization of biological pigmentation at the spaces of representation. Whiteness thus becomes a pigmentary passport of privilege. Dei (2011) reasons therefore that whiteness has no meaning outside of colonialism and oppression.

Applebaum (2005) further points out that:

The discourse of meritocracy functions to marginalize certain groups of people by allowing whites to direct attention away from their own privilege and to ignore larger patterns of racial injustice. The assumption 
that people get ahead as a result of individual effort or merit conceals how social, economic and cultural privileges facilitate the success of some groups of people but not others. Moreover, it allows the privileged to see themselves as innocent bystanders rather than participants in a system that creates, maintains and reproduces social injustice (p. 286).

To young Africans therefore, colonization and racism brought about major severance (that Frantz Fanon referred to as amputation) of the colonized peoples first, from themselves, and then from their environment, culture and knowledge base. Thus alienated from their languages (Wa Thiong'O, 1986), knowledge of their past, and their environment (Sefa Dei, 2011; Lebakeng, 2010), and having lost touch with their identity and humanity, devoid of liberty and freedom as human beings (Fanon, 1967), and completely oblivious of the basis of their humanity, that is, spirituality (Sefa Dei, 2011; Wane, 2007), the colonizer's imposed ways of knowing became reified, essentialized and taken up as the way of salvation from the supposedly "primitive" entrapment the colonized knew before the encounter. After the partitioning, and subsequent colonization of Africa by Europe for instance, the West realized that the task was not just to rid the continent of its epistemological and ontological bases and cultural heritages but to also contest the legacies of earlier Arab colonization and cultural vitiation. In his Black skin, White masks, Frantz Fanon (1952) depicts his view on human nature which must not be encased or subjugated for it is human destiny to be free. The annexation of Africa, imposition of foreign rule and cultural suppression coupled with ruthless brutality meted out on the colonized bodies, was in Fanon's view a measure of "violence" that left significant damage on the psyche of the colonized; depriving them of their freedom, and liberty. To Fanon each of these tasks might require violence for decolonization is as much a "violent phenomenon" as colonization itself (p. 99). The acculturated young Africans became persistently irrelevant to their cultural environments and would emigrate to Europe as a measure of claiming whiteness. These colonized and racialized bodies foresee freedom in claiming whiteness because whiteness can be claimed and embraced by non-white bodies. Criminalizing these migrants, restricting them and denying them the freedom they crave is still another display of power imbalance and a reenactment of race at the disposal of the dominant social group. Therefore the engagement of anti-racism is also about acknowledging that despite the relative saliencies of different identities, and the situational and contextual variations in the intensities of oppression, race privilege and white identities are profound (Dei, 2011). Again rupturing the ontological question of race Sefa Dei (2011) not only affirm the reality of race but stresses its saliency. This apparently is because discourses of racial realism project race as real not because of any biological essences but because it has material, political, emotional, symbolic and practical consequences, which is bolstered by the effects of its social and political ramifications. Although race has featured tremendously in certain social representations, it is incapacitated without such colonial tools as repression or outright erasure of most of the heritages of the colonized for instance history and language. Also tools of cultural encapsulation which includes subversion of religion healthcare and processes of knowledge creation and dissemination through neo-colonial projects are massively deployed resulting in erasure of individual humanity of the racialized bodies. Anti-racism starts with acknowledging the self as an important entry point, for according to Dei (2011), if there is one thing that cannot be appropriated from the subject it is the body; and with it the subject's intellectual agency, for instance, the agency of the colonized, racialized, oppressed and minoritized. In other words, while "embodiment" is about the particular experiencing of the body and how it is acted upon in a given socio-historical and geo-political context, the notion of embodied knowing is about coming to know, which remains a perspective that can be attained by developing an attachment or a particular connection to knowledge. To the culturally, economically, politically displaced young Africans, the knowledge of the privileges of whiteness that was etched into their medulla oblongata by the repressed trauma of colonization and neo-colonial subjugations need a vent. The scorching heat of Sahara and the boiling waters of Mediterranean weighed together against the trauma of loss of ones humanity becomes as much a child's play that these youth remain undeterred to reach Europe even by the threats of death.

\section{Border as a Marker of Identity and Site for Contestation of Citizenship}

Revisiting North American border restrictions, Browne's (2007) work shows how the identification and classification achieved through the Canadian Permanent Resident Card, PRC help to shape individual and collective imaginings about citizenship and belonging to the Canadian nation. The work engages post-structuralism in making sense of and detestation to Canadian PRC as a "signifier" of authentic subject and citizenship, which Browne describes as both positivist in view and essentialism in practice (Browne, 2007: p. 34; Belsey, 2002: p. 
15). Browne recalls the case of Brandon Mayfield to argue against the assumption of infallible objectivist biometric technologies. This implies that the state's assumption that the PRC and surveillance technologies encode infallible "truth" about its subjects through which to identify and differentiate people is brought to question, for post-structural theorizing encourages deep suspicion of universal claims of singular "truth" (Rosenburg, 2004: p. 36). Browne's (2007) contribution to the debate on transnational border policing and racialization with reference to the migrant Other's subjectification is relevant to my paper due to its portrayal of the power dynamics of the Canadian state in relation to its constituted subjects (foreigners applying for PRC). But she seems to have done a meta-narrative of Canadian PRC intervention in which the states of Canada and US, and their private/public allied corporations without restraint; and with preconceived notions of who becomes the "trusted traveler" and/or the illegal migrants, constructed the positive and negative spaces into which each of these categories must fit. I regret to frown at Browne's view of the Canadian PRC as a marker of identity, and hope to differ by asking if it was possible for the PRC to create double tiers of citizens in Canada — real and imagined citizens — each distinguishable by skin color or the extent to which certain recognition and privileges are bequeathed notwithstanding possession of valid identities for citizenship.

Browne's posture resonates with Sharma (2005), which invokes and troubles the unlimited sphere of the hegemonic influence of the Canadian state over its subjects. Border policing is exerted through territorial border surveillance and issues of national identification are not just for those constituted as citizens through the possession of citizenship status, rather it is even more critical for people constructed as the nation's Other or aliens, who inhabit spaces controlled by the Canadian state. Examining Canadian national policies on immigration, Sharma reasons that: "identifying oneself through the reference to the 'Canadian nation' works to secure legitimacy for the subordination of people who are legally and socially made into 'foreigners' or non-Canadians in Canada” (p. 9). Considering the line of argument towed by Browne (2007) and Sharma (2005) the question remains whether the migrant subjects themselves in any way contribute in the process of subjectification they face at Canadian/US border? A divergent view emerges however. Goldin, Cameron and Balarajan (2011) paradoxically designed a non-polarized world, a power-balanced model through which to advance their notions of two factors compelling receiving states to securitize and control their territorial borders. The work argues that concerns about globalization and terror are the major developments compelling the immigrant receiving economies to restrict their borders. According to Goldin, Cameron and Balarajan's work, "accelerating globalization, which has been accompanied by intensifying global competitiveness and a "war for talent" to attract migrants that can feed innovation and economic growth" (p. 153). The atmosphere prevalent in the world constructed in the work of Goldin, Cameron and Balarajan is inconsistent with the reality of a polarized world in which the industrialized North, that is, the colonizers detect who migrates, and to where? The South as is apparent from the narrative is constructed not as part of the competitors in the global political and socio-economic theatre (except as a supplier of terrorism) and as involuntary supplier of undesired talents and raw materials; a justification therefore for the North to securitize its borders against the unwanted vagabond. The question my paper continues to advance in this neo-colonial, and neo-liberal rhetoric that symbolized a regurgitation of justification for colonization is, has the Southern states equal opportunities to gatekeeping and border surveillance as the West? Why do Northern nations always violate their border security policies when it comes to conscripting Southern elites to work in the North? How might we begin to understand the invasion of Southern border spaces by Northern states and alliances during military involvements? Only a deviation from the paradigm insinuated in Goldin, Cameron and Balarajan's work would clearly point to the lopsided power imbalance in the North—South border control and surveillance systems.

Shea (2012) explores the importance of non-status immigrants in the conceptions and operations of citizenship in Canada. Her work is invaluable to my paper for underscoring the significant role non-status migrants play in the construction of Canadian citizenship. The major contribution of Shea's work to the discourse on non-status immigrants is its argument that further perpetuation of immigrants' subjugation happen when activist groups, during their advocacy, in a bid to obtain assistance from state, become obsequious to state's ideologies, policies and plans. She argues that such ambivalent disposition or duplicity of function weakens even the most radical arms of non-status activism, as their activities reproduce the socio-political oppression they seek to redress. In a similar work Nyers (2010) studies the active socio-political engagements of groups of non-status migrants and refugees to uncover how their operations challenge government's established models on citizenship, and membership of the social community. In a view divergent to the popular representations of refugees and non-status migrants as passive players in the border politicking, Nyers' work made reference to irregular mi- 
grants' activism in Australia, Canada, and Egypt and it reasons that: "migrants with precarious status are emerging as key protagonists in global struggles concerning freedom of movement, social recognition, worker protections, and the right of asylum” (p. 127). To further buttress this point, the government of Canada allows entry to refugees. "A convention refugee and person in need of protection are people who are unable, or by reason of their fear, unwilling to be protected by their country of origin" (Immigration and Refugee Board of Canada, Interpreters Training Manual 2010, p. 7). This definition implies a power relation in which the immigrant is neither hapless nor helpless as Browne (2007) depicts. Highlighting the urgent need for an extended intellectual and political debate on "world without borders", Anderson, Sharma, and Wright's (2009) work, which is consistent with Jonathan Moses' (2006) earlier argument for a world without border, insists that:

“...the simultaneous process of granting more freedom to capital and less to migrants is far from a contradiction and is in fact a crucial underpinning of global capitalism and the equally global system of national states. The growing restriction on the freedom of people to move has not led to fewer people crossing nationalized borders. Exactly the opposite: today more people are doing exactly this than ever before (Anderson, Sharma, and Wright, 2009, p. 5).

It is critical to observe at this juncture that the methodology in Browne's (2007) work early cited, which engages an analysis of few print-media reports on the experiences of PRC subjects instead of using survey and/or ethnographic interview is what I found to be a bit of methodological, or more specifically instrument problem. By so doing she invisibilizes the "subjects" and therefore not only trivializes the illegal immigrants' identities, but reproduces an imbalance in power structure between herself, the author and even the categories of immigrant subjects her work is set to advocate for. Objectivity, Rosenburg (2004) warns, is only assumed from the perspective of the privileged (p. 41). The questions I raise here are: who own these newspapers? Whose interests and policies are those print media's news coverage on experiences of the "trusted" travelers and "risky" aliens reflecting? The answer is of course, the neoliberal state and capitalist public. Could these media biased by total absence of proximity to its subjects have been a reliable source of immigrant experiences as the author assumed? If not, what then is the justification for the choice of secondary source instead of primary source that interview could have provided? Browne (2007) nevertheless, successfully exemplified the complexities of identity commodification as strategized through transnational border surveillance, militarism and commercialization of risk management which I think finds relevance in the prescriptions of neoliberal ideologies of autonomous self, bureaucratization, responsibilization and market oriented strategizing (Davies, 2006). However in Browne (2007) individual subjects or travelers are constructed as passive recipients and victims of state-control apparatuses in a neo-liberal regime. Judith Butler asserts that subjection is the subordination brought on itself by the subject which is a precondition for agency (cited in Davies, 2006). Although I will look at these subjects through Foucauldian lenses in which subjects are seen as desirous of freedom, this means the subject submitting to subject-hood or becoming "a good disciplinary subject” (see: Davies, 2006: p. 426; Belsey, 2002: p. 71). Yet as power imbalance always produces resistance, the surveillance, disciplinary and border control technologies must be and has been resisted by those dubbed illegitimate non-trusted travelers too, for in Foucauldian perspective, even the disciplinary subject is capable of resistance. I will further reason that the Canadian PRC and events of its assignment, while part of the bureaucratic governance of permanent residents, which is a demographic segment of Canadian population; also produces the monitored and controlled Canadian citizen as an effect because once at the border, the citizens would pass through the same border screening processes as do the immigrants until the system certified them to be 'bona fide citizens'. As Scott (1991) notes "Being a subject means being subjected to definite conditions of existence, conditions of endowment of agents and conditions of exercise” (p. 793). This brings me to the notion of responsibilization which pervades the era of globalization. Here individual subjects are required by the state to be only responsible to self and shed responsibility for others, but actively participate in surveillance and control (Davies, 2006). And as Foucauldian subject becomes a "good disciplinary subject", it is capable of resistance and by engaging in such, it emerges in freedom (Brown, 1993: p. 397). But the freedom accruable to the citizenship conferees who are not "Whites" or privileged bodies must be contested at international borders. For instance two Canadian citizens on international trip from the same organization, one, an European-Canadian and the other an African-Canadian arrived at a Toronto airport. The latter was held for some more scrutiny of his Canadian passport while the former worked through hitch-free. 


\section{Border Gatekeeping and the Migrant Other: Intersections of Gender, Race, Disability and Legal Status in the Context of Youth Migration}

It is important to explore the influence of race, gender, disability and legal status on the flow and experiences of the $21^{\text {st }}$ century transnational migrant subjects. Valiani (2012) draws from scholarly writings on gender and migration to accentuate the pattern of feminization of migration flow over the past five to ten years which she traces to four phenomenal shift in global socio-economic structures to include: improved statistical visibility of women as migrants, increasing participation of women in most migration streams, growing unemployment among men in migrant-sending countries, and increasing demand for labor in feminized sectors in migrant-receiving countries (Valiani, 2012). The opinion of this paper is that more than anything else, the changes imposed by colonial subjugation and hegemonic control of the socio-cultural norms, values and mores in developing countries, has greater impact on the gender constituents of migrating categories. It is also the view of my paper that the effects of colonization on mostly Indigenous societies of the South tended to subvert and modify gender roles in these economies (see: Nwalutu, 2004, 2014), which might account for the increased recognition of women's roles in the flow of international migration. In fact, DeLaet (1999) observes that of other gender categories, women constitute the largest number of the world refugees, and Kelson (1999) similarly reasons that about half of the immigrants conferred with permanent resident status in the US between 1983 and 1993 were females. This apparently suggests increasing involvement of women in the $21^{\text {st }}$ century transnational migration, for which Kelson reasons that it was no longer safe to overlook the impact of transnational migration on female migrants. Drawing on figures projected in the United Nations Department of Economic and Social Affairs, DESA (2006) indicating that female international migrants constitute almost fifty per cent of all migrants in the year 2005, as compared to forty seven per cent in 1960. Valiani's (2012) work elaborates on the complicit activities of some migrants' states of origin in the preparation and export of labor to receiving countries (mostly to Western economies) as alternative means for financing their foreign exchange deficit. She cites the case of the Philippines' state policies in establishing the country as the leading international exporter of labor. By challenging the popular Push and Pull explanations, Valiani corroborates Adepoju (1993), which underscores the role of structural adjustment programs of the 1980s as giving rise to low wage employment, and in turn, labor migration. She stresses that:

It is the historically-entrenched structure of the Philippines state which is underlined here. It is argued that the Philippines state embarked upon a labor export policy, from the early 1970s due to contradictions arising from trade relations shaped under colonialism, severely unequal land distribution, and weighty US

American political influence (Valiani, 2012: p. 114).

While her work is consistent with the arguments of Adepoju (1993), Sassen (1988) and Amy Chua (2003) respecting the role of the West in the formation of Southern migrant subjects, and the flow of labor from developing countries to the Western industrial capitals, it falls short of revealing how the potential South-North Philippines migrant subject (for instance) are complicit to their immigration experiences. Also it has little or nothing pointing to the demographic constituents of the migrant women population. Apparently, Valiani (2012) subsumes the other migrant categories such as the independent youth migrants, migrants with disabilities and the unaccompanied minors under adult migrant population. It is only by separating these demographic categories that we would earnestly begin to address the insidious strains in the experiences of youth transnational migrants. In her critical message to activist groups advocating for female migrants held by the Canadian Border Agency, Sharma (2005) reacts:

“The women and children-but significantly never the men-among these particular migrants were labeled as "victims of trafficking” at various times by some feminists advocating for them as well as by then Minister of Citizenship and Immigration Canada, Elinor Caplan. The fact that they arrived on rusty, unsafe boats after a long, harrowing trip made this seem like common sense. After all, who would voluntarily embark on such a dangerous journey without being forced? Failing to regard the fact that male migrants also traveled under these same conditions, those feminists employing the conceptual frame of trafficking tried to shift the representation of the women migrants as a danger and a threat to one where they would be seen as victims (p. 93).

Attention to the victims of contemporary migration and border restriction policies parochially are focused 
largely on female and children, understandably so. But overlooking the various subcategories of individuals constituting the migrant population invisibilizes the excluded bodies and minimizes the rationality of modifying existing policies to improve their migration experiences. It is crucial to point out that as attention is devoted to fighting human trafficking in current transnational migration, especially as it affects human flow from the developing South to the industrialized North, scholars should endeavor to sift through the mesh of efforts of a large number of indigent voluntary migrants who use any available opportunity of escape to transit to their destinations. The wide speculation about existing trafficking syndicates lurking to prey on passive individuals, or dissuade the citizens to become trafficked migrants begs urgent reexamination. Understanding the thought process of intending migrants and their determination to reach their goals at all cost might bring about a shift in the view of migration scholars, and chart a new trajectory, implying possible modification of existing policies for effective handling of the burgeoning cases of young adults' migration. Gould (2011) reaffirms that:

...the current "law enforcement" response to trafficking is unlikely to lead to a reduction in the prevalence of trafficking. Indeed, as several authors point out, making it more difficult for economic migrants, particularly women, to cross borders is more likely to lead to [them] relying on unscrupulous third parties for assistance (p. 47).

Inference from Gould and other contributors in this review, show that the focus of most arguments is on the vulnerability of migrants, or on supposedly vulnerable migrants. Realistically however, migrant individuals, irrespective of their social category, become the more infantilized, and reduced to passive irrational victims of the prowling transnational migration syndicates, which hardly is the case because migrants are rational, active participants in the entire process of transnational migration. In addition, a little or nothing is yet done to contextualize the transnational border crossing experiences of migrants who are also living with one disability or the other, by this I do not mean persons who sustained disabling injuries in their migration process, but those living with disabilities in their countries of origin who also felt the drive to migrate to Oversea countries for temporary or permanent stay. Until conversations on migration are broadened to encompass various categories of migrants, and the interlocking chains and processes of events that generate their lived experiences, full knowledge of the global migrant subjects would remain mere conjectures. This perspective of reasoning emanates from the understanding that terminologies and categories matter so much in the perception, considerations and interventions migrants receive at the border and within host society, as spelt out in the International Maritime and Refugee laws respectively, Melissa Phillips argues:

Assuming that all people have the same reason for leaving their homes and getting onto boats, that all people rescued at sea are migrants and that there is a one size fits all policy response misrecognises the heterogeneity of this group. Such heterogeneity includes country of origin, gender, age, (race and ability, addition, mine) and family make up including pre-existing links to Europe (Phillips, 2014).

Many youth migrants are actually situated in the intersections, and often at the margins of these categories outlined by Phillips. Also clarifying between categories enable scholars aspire for a nuanced narrative of individual migrants as more authentic account, and epistemic saliency (lived experience) of the migrant subjects in question. This is in opposition to the hyped-up narratives of the media that often generate unbalanced and therefore unfair public opinion (and of course policies) that negatively affect migrant individuals in their host environments. A clear understanding of the demographic constituents of migrant population involved in AfricaEurope migration and critical information about their cross-border ordeals will expose how all categories of subjects are labeled together and subsumed under one title: "Boat people” (see: Pisani, 2012; Phillips, 2014; Frenzen, 2014; Sunderland, 2012) at the receiving societies, which also permits of no distinction in terms of how vulnerable individuals such as minors (children), women and migrants with disabilities are subjected to policy restrictions at the border.

Through unbiased investigations (and understanding) of migrants lived experiences we might expose the drain youth emigration constitutes to the developing countries they are leaving behind; the structural and socio-economic problems they encounter at the host societies and the impending consequences for all stakeholders. Often voluntary migrant individuals, especially those from developing economies are undervalorized as victims of peddling cartels or trafficking syndicates (see also Sharma, 2005b; Valiani, 2012; Falola \& Afolabi, 2007), which provokes serious thought on the Western imagining of racialized migrant 
bodies. Migrant individuals are demeaned, prejudicially criminalized, invisiblized and therefore, depicted as devoid of reasons, illiterates, and uncivilized (Sharma, 2005a), hence must be spoken for. It is within this context that often duplicitous activists in host societies connive with their domestic governments to be carrying out anti-immigrant campaign while pretending to be advocating for the non-status immigrants. The ambivalences depicted above might have led social science and migration scholars to portray migrants as devoid of agency-being victims of their own state architecture-and those of Western neo-colonial propagation (see: Valiani, 2012). In the work of Valiani specifically, the question would then be: how has her argument, as plausible as it is, positioned the agency of the transnational migrant individual? Sharma (2005b) examines the past and existing discourses and praxis of anti-trafficking campaigns in Canada and argues that these campaigns in the context of global North, which frequently are organized by feminist activist and other NGOs, are anything but initiatives in favor or moral considerations of migrant individuals. They are rather the modified organs of anti-immigrant debates and policies that are aimed at the Othered migrant bodies. Sharma couldn't see any distinction between these campaigns and the previous attempts that were mere collusions with the government-sponsored transnational securitization and surveillance schema intended to criminalize voluntary independent migrants from the South. Yet at the same time, transnational Northern migrants to the South for whatever purpose or intention-leisure-seeking; equipped to research and speak for speechless Southern folks; or on exploitative mission of their home governments-are reified as heroes and heroines of salvation. I would argue therefore that dubbing border-crossing migrants-whose demographic categories are often a mixture of different gender, age, ability and race, victims of human-trafficking-invisibilizes and dehumanizes them and denies them of any iota of agency and self-determination as individuals. Nonetheless they are not without agency, if we consider Fanon's (1952) argument on affective cost of imposition of domination on the colonized bodies. A traumatic re-experiencing of self, results in loss of a person's humanity as an individual; then a psychological re-adjustment of disposition towards the colonizer, his source of trauma. Fanon stresses: “The problem of colonization therefore comprises not only the intersection of historical and objective conditions but also man's attitude towards these conditions” (p. 65). In fact, a deconstruction of Valiani's (2012) work on the roles of the Philippines state in the citizens' transnational mobility would show how acquisition of Western education and training repositions the citizens to perceive the Indigenous Philippines' traditions and environment in the spectacles of the West (Appadurai, 1996) and by themselves nursed and executed the desire to migrate to the Americas. The Philippines migrants were therefore neither devoid of agency nor at any rate to be considered victims of their state's capitalist motives, nor are they victims of migration syndicates or organized criminal gangs. In Sharma's (2005a) contribution, men, women, youth and children migrants who arrived in Canadian territorial water were detained by the Canadian Coast Guards along Vancouver coast, but only the women were spoken for as victims of migration syndicates. If the conditions of their arrival, mode of flight (type of transport used) and apparent disclosures attested to their bids to escape from unsafe domestic environment, they were active players in their migratory experience and should have been considered as such. Were the male migrants deportees yet another victims of racialized border surveillance systems targeted by the state apparatuses to screen off the "untrusted travelers" (Browne, 2007) while the detained and accepted few female folks served as tokenization to placate the wrath of critics of Western segregated borders? The position of my paper again is that the men and youth in the boat who were detained and subsequently deported to their purportedly hostile countries (just as their female folks) should have been received as active asylum and refugee claimants (not as victims of human traffickers) like their female folks. Sharma's view resonates with the position of this work that it is the cognizance of the agency of individual migrants as active players in their migratory efforts that would reveal the disruptive roles of global system of capitalist expansion. This awareness would expose how the deliberate disruption of peoples' indigenous socio-economic structures by the colonizing world has shaped and continues to shape the current face of forced-mobility of the Southern migrants who are harvested as surplus labor in the industrialized North.

\section{African Migrant Youth and the EU Border Fortification in the Light of Global Policies}

Africa migrant youth engaging on a sea travel to Europe either in search of "better life" or escaping from war and persecution from their countries of origin use any of the varying land and sea routes trans-Sahara via: Libya, Egypt, Tunisia and Morocco, Algeria across the Mediterranean Sea to the Island of Malta or Lampe- 
duza, Italy. They also travel through Spain's Canary Islands in the Atlantic Ocean or via the Strait of Gibraltar. It is estimated that a total of 58000 migrants arrived in Europe in 2011 (Human Rights Watch, 2012). So long as these trips are not regularized (not embarked on with proper traveling documents), they fall under emergency situations created by human-made or natural disasters, and therefore are altogether a risky experience. According to Sunderland (2012):

Some of those attempting by land and air-the vast majority of irregular entries into Europe-take considerable risks: hiding in and under trucks, stuffed into car trunks, crammed into containers where lack of air, food and water have claimed hundreds of lives. Discover en route or at the border can mean mistreatment at the hands of smugglers, unwilling transporters (e.g. truck drivers), and border guards; detention or summary return to a country of transit or country of origin, or as Human Rights Watch, has documented, being dumped in the desert along remote stretches of North African borders and left to die (p. 3).

The coastal European countries of first ports of entry includes: Malta, Greece, Italy and Spain and these have on continuous basis, and in a bid to circumscribe all efforts of migrants from Africa to reach European shores, maintained cooperation deals with countries of departure in Africa. Joint surveillance is imposed on developing economies of Africa with EUs technical, financial and persuasive power for border migrants' restriction (Frenzen, 2014; Sunderland, 2012). The EU border agency received an express injunction in 2011 to respect International Human Rights laws and support sea rescue efforts while carrying out its functions (2012). But this injunction goes against the grain of Frontex' original mandate of which priority of operation is to prevent migrant boats from landing on EU member states territorial waters. This objective has often been carried out to the letters, preventing migrants from accessing rights applicable within the EU territories.

\section{EUROSUR as a Double Fortification}

The European parliament and European Council met and operationalized a draft to establish a new fortification based on distance surveillance with advanced technologies. EUROSUR was formed to inter alia, use technological devices such as satellite imagery and drones to monitor the Mediterranean Sea and North African coasts. Exception were made to the effect that the draft should pay priority attention to EU member states, persons in distress at sea, children, asylum seekers and victims of human trafficking, as well as person(s) in need of medical attention. All these are in line with the UN provision to safeguard human rights at the international waters (Frenzen, 2014; Newland, 2003; Phillips, 2014). In an analysis of EU Regulations for FRONTEX, coordinated surveillance of external sea borders was foremost in agenda, and the priority was aimed at enhancing protection (at least in writing) of migrants who must be intercepted or rescued. Interestingly, such a cogent and extremely critical document permits many obvious loopholes that enable state agencies of EU and its member states wash their hands off any blames when migrants related tragedies occur on EU territorial waters or areas within its jurisdiction. One of such loopholes is that the regulation was silent respecting the circumstances migrants interception occurred in territorial waters of a third state (non-member state of EU). This raises concern over push-back. It has been observed for instance, that prior to Libyan revolution, Italy extended its borders to Libyan coasts by proxy. This means it was patrolling Libyan coasts with the sole aim of intercepting and disembarking migrant boast carrying Africans, since Libya is one of the coasts of departure for migrants from Africa (Frenzen, 2014; Newland, 2003). In 2009, Italy intercepted migrant boats with individuals in distress over Italian coast territorial waters, and instead of rescuing them, deported all the occupants back to Libya, not considerate of the implication of such a drastic action for the various category of migrants on board the boat (Frenzen, 2014; Sunderland, 2012). This push-back strategy did not forestall the trip of subsequent migrant boats, but it further raised the death toll of hapless African migrants including women and children.

The regulation also prescribed that boats intercepted in the territorial sea or contiguous zone of any EU member state should be disembarked in same territory. This specific regulation provided a condition that allows authorities to still order an alteration of course of migrant boats that have made it thus far. This action is in flagrant violation of not just the fundamental right of the migrants but the International Refugee laws and International Maritime laws that demand that EU member states should under the circumstance discussed above, use all available means to identify intercepted persons so as to afford migrants opportunity to assert a non-refoulement claim (Sunderland, 2012). The aggressively heightened anti-immigrant operations of FRONTEX beyond EU territories informed a paradox that requires closer details—-for at the auspices of FRONTEX many more mi- 
grants death were recorded in the Mediterranean Sea (Sunderland, 2012). For instance, during the 2011 Libyan revolution that ousted Col. Gadhafi, FRONTEX sent its joint operations consisting of ships and aerial surveillance to Libya as back-up for Italy in order to frustrate influx of migrants from Africa. The North Atlantic Treaty Organization, NATO also deployed 21 ships at the Mediterranean as a tactical bid to foil arms supply to Gadhafi regime (Sunderland, 2012). The intensification of Libyan crisis, expectedly, drove an ethnically mixed-multitude of immigrants in Libya to the sea. These ethnically mixed groups of immigrants were escaping the onslaught of the Libyan dictator, Gadhafi but the incident that follows would begin to unsettle the humanitarian angle of EU's, NATO's, UNHCR's and IOM's operations on the Mediterranean Sea. While dallying over whose responsibility it was to rescue the boat conveying a batch of migrants out of Libya, the West watched 63 of them including 20 women and 2 babies die in the infamous "left to die" case:

One particular event, reported by the international press, provoked widespread public outrage. In the case of what is now referred to as the "left-to-die boat", 72 migrants fleeing Tripoli by boat on the early morning of March 272011 ran out of fuel and were left to drift for 14 days until they landed back on the Libyan coast. With no water or food on-board, only nine of the migrants survived. In several interviews, these survivors recounted the various points of contacts they had with the external world during this ordeal. This included describing the aircraft that flew over them, the distress call they sent out via satellite telephone and their visual sightings of a military helicopter which provided a few packets of biscuits and bottles of water and a military ship which failed to provide any assistance whatsoever. The events, as recounted by these survivors, appeared to constitute a severe violation of the legal obligation to provide assistance to any person in distress at sea, an obligation sanctioned by several international conventions (Heller, Pezzani and Situ Studio, 2012: p. 9; Strik, 2012).

This case accentuates the paradoxical outcome of deceptive propagation of international orders-it is a violation, legal and binding when and only when racialized and marginalized bodies of developing economy—are not the victims. According to sources, the small boat ferrying these migrants out of Libya ran out of fuel and supplies. One of the passengers used a cell phone to communicate an Eritrean priest in Rome who alerted the Coast Guards and NATO Headquarters in Italy. The 1979 International Convention on Maritime Search and Rescue (SAR Convention) enjoins governments and all stakeholders to: “... ensure that assistance be provided to any person in distress at sea... regardless of the nationality or status of such a person or the circumstances in which that person is found” (ICMSAR, Chapter 2.1.10). The 1982 United Nations Convention on the Law of the Sea (UNCLOS, Art. 98: 2) also passes a responsibility on every coastal state party to: “...promote the establishment, operation and maintenance of an adequate and effective search and rescue service regarding safety on and over the sea and, where circumstances so require, by way of mutual regional arrangements co-operate with neighbouring States for this purpose”. (Heller, Pezzani and Situ Studio, 2012: p. 10). Nevertheless, the Italian authorities, and NATO military helicopters and warships came in contact with the boat and offered them no meaningful help. The boat drifted for 14 days on Mediterranean and was pulled back to Libyan coast by a strong current. On arrival the ill-equipped migrants have lost 61 people. Only 9 survived and one later died in Libyan jail. While some differences between oral testimonies occur on specific points and while there are some instances in which more data would have been desirable, overall a coherent picture emerges from the synthesis of these disparate bodies of information, a picture that demonstrates how the migrants were led to a slow death despite repeated contacts with several parties. An abbreviated summary of key events is outlined as follows (Heller, Pezzani and Situ Studio, 2012: p. 10).

This travesty of humanitarian work quickly strikes a chord with the apparently tactless, astute but revealing response of Mr. Valeri Artemienko during the court case in 1992, in France, indicting him and his crew for murdering 8 African young migrant stowaways. Artemienko, now in life jail mumbled out to the embarrassment of the duplicitous Europe: "Europe will thank us for what we did" (Davies, 1995). It was the testimony of Ukrainian sea Captain, Alexander Vinniski that exposes part of the reality or the dilemma of European policies that impelled the crew to the murderous rage:

The terrible thing about this situation," he said, "is that this crew went to the other side of the world and met people who were just as unhappy, people who were just as anxious to find a better life. They were afraid they would lose their jobs if anyone discovered the stowaways (Davies, 1995).

It might sound worrisome that ship stowaway was the most accessible opportunity irregular migrants made 
use of to the extent that in1999 alone, Britain witnessed a record high 54,000 stowaways in Sea Ports and Airports, so it is likely that the 8 murdered young men were not the only stowaway migrants killed in similar horrific encounters. The question is who actually should be held responsible for incidents like this and many more that go unnoticed?

\section{Aggressive Border Restrictions and Shifting Responsibilities: They Must Arrive Dead or Be Sent Back}

Towards the end of 2012, Italian authorities disputed the account of about 56 survivors who claimed that the boat conveying them from Tunisia capsized near Lampeduza. The authorities believed differently, they reasoned that since there were no floating bodies or debris from the boat, the migrants could have been dumped at Lampione by human traffickers who shortly returned to Tunisia. They insisted that two bodies recovered within the same period were from a different mishap location (Frenzen, 2014). The invisiblization of the agency of migrants as active participants in migration process raises more questions about the expectations of the EU authorities for the intercepted migrants, and who is really responsible for the tragic incidents sequel to increasing militarization of EU sea borders. In an interview with the FRONTEX Director, Ilkka Laitinen in 2013, the FRONTEX boss made yet a startling disclosure in response to a question about accountability of his Agency in occasions of flagrant migrants' right violation resulting in bodily harm or death. He argues that Frontex is of the opinion that the operation and any potential human rights violation are actually the responsibility of the member states; not FRONTEX (Frenzen, 2014). I will continue to assert in this work that in the context of human rights and fundamental rights of migrants, much of the so called provisions and conventions of international regulatory bodies are carrot and stick apparatuses; a neo-colonial tool in the hand of the dominant North against the developing South, since their provisions do not apply equally to citizens of both the industrialized countries and their racialized and marginalized Other. Regional agencies and military organizations such as FRONTEX, NATO and other NGOs in the EU member states are not under any supervisory authority that would compel their compliance with international regulations. For instance, in the case cited earlier involving the death of 62 African migrants, Spain, the United States, Italy, and the United Kingdom discretely refused to render accounts to the EU and UN inquest, about their military engagements in the Mediterranean Sea during the tragedy. The parliamentary Assembly of the Council of Europe (PACE), condescended to request further investigation into the incident, but that was not heeded also.

\section{Discussion}

The number of Vietnamese refugees taking to the South China Sea during the country's civil war was enormous. Many of them, like some African migrants today crammed into non-sea worthy boats to escape the onslaught of war. Many merchant ships that came in contact offered to rescue the migrants, and according to the international maritime rule, they must also disembark them at the nearest country. Malaysia and Thailand felt so overwhelmed that they refused to receive them into their territories, so the ship owners who observed the "rescue at sea convention" involuntarily had to bear the cost of rescuing the migrants (Newland, 2003). I would at this juncture reflect on what happened to Ukrainian sailors who murdered African stowaway youth. As Nick Davies insists, "these murders were committed as a direct and predictable result of laws that have been passed and blessed by France and Britain and almost every other government in the European Union” (Davies, 1995). It is a justified deduction then to argue that the killer-crew acted under the pressure of European Union to violently destroy the lives of those they constructed as aliens, deviants and law breakers. It is an intractable puzzle though, if the crew could have acted differently, were the murdered eight young men European stowaways, and this remains a point of cogitation and sober reflection. The EU carrier-liability law with a fine of £75.7 million (Davies, 1995), which aims to cripple the fiscal base of ship owners caught wittingly or otherwise, conveying irregular migrants to Europe, thus became the death warrant for crews to cast overboard any irregular migrant they discover in their vessel. In 1985 the United Nations High Commission for Refugees was moved by instances such as the Vietnamese refugees case to put in place a number of emergency measures, which included providing to reimburse owners of vessels for cost incurred during sea-rescue exercise. The UNHCR provision also includes, to publicly commend the gestures of sea-farers who rescue migrants (Sunderland, 2012). The tradition of sea faring has similar outstanding codes of which is to respond to migrants' distress calls (see Strik, 2012; Interna- 
tional Convention for the Safety of Life at Sea, 1974). Countries like the United States, Australia, Britain and Germany might actually press charges against any crew that failed to respond to distress call at sea (Newland, 2003; Phillips, 2014). Presently the codes are contained in the UN Convention on the Law of the Sea, 1982, and International Maritime Convention on Maritime Search and Rescue, 1979. In any of these conventions the crew is enjoined to render assistance without prejudice against migrants' ethnicity, profession, nationality status or circumstances of the distressed individual (Phillips, 2014). The difficulty in this code of conduct is the imperative that the rescued person(s) must be disembarked at a safe location for the rescue to be considered complete, and it must be to the nearest location to the point of distress. The danger of this segment of the code of conduct at the international waters is that when a Refugee is among the rescued individuals, such a person, also by the provision of international law, must not be returned forcefully to a country her/his life or freedom would be in jeopardy. It could be inferred from the 1951 Convention on Refugees that no country in reality-including those that acceded to the convention-is under obligation to accept refugees.

\section{Conflating Transnational Laws at the Peril of African Migrant Youth}

The area of interest at this juncture is the conflicting intersection between domestic policies and maritime laws of the receiving states and international refugee law. Ship crews are under obligation to rescue sea migrants who run into distressful conditions, but they also have to transfer the rescued individuals to the nearest safe haven to save cost for themselves as well as in compliance with the provisions of the laws. But no state is obliged to accept rescued persons because if there are refugees among the rescued individuals, the host country might be violating the law by repatriating them to their countries of origin. Australian and Italian naval vessels have been accused in the resent times of watching migrants die at sea and countries like USA, France, Italy and Australia have not only intercepted and repatriated migrant boats intending to dock in their territories but diverted them to different locations to disembark, as a deterrence to impending irregular migrants (see Newland, 2003). The question however is, has there been reduction in cases of migration into European borders via the sea or more specifically, are we foreseeing any reduction in the flow of migration of African youth to Europe? The view of this paper is that the root cause of youth migration must be addressed if the phenomenon would be minimized or eradicated. Tackling youth migration would not be achieved by the existing policies and practices of border restriction and migrant management as is presently the case. The various states of origin (developing or industrialized) must be involved in the study geared towards understanding the drives of youth migration, bearing in mind that one size fits all strategy might not always work particularly when it comes to youth migration. Besides, the understanding that migrants are either political or economic refugees, which led Bjarnesen (2014) to reason that labor migrants and refugees are intertwined also brought about the notion of mixed migration. But as Phillips (2014) argues, migration evokes a polarized atmosphere of competition between immigrants and the citizens of a host country. Meaning that, among mixed migrants in a rescued boat, refugees and asylum seekers would be predisposed to receive more empathy from the citizens than do economic immigrants. For migration stakeholders and policy makers, there is however need to tease out distinct categories of youth migrants so as to properly analyze, and make provisions that might be tailored to and expedient for each group's needs.

\section{Conclusion}

The challenges inherent in the intersection of international laws and codes of practices with respect to the operation of EU state's border officials towards migrant individuals, especially migrant African youth, is actually a statement about the state's commitment and compliance to its obligation and to the tenets of universal human rights law. EU member states' adoption of criminal laws that stipulate offences solely to check and restrain migrants is in itself a major contradiction and challenge for the international human rights laws that permits of no discrimination of individuals based on gender, nationality or status. It apparently becomes even more conflicting when one segment of the law permits nationals of a state to enter or leave its territories while foreign migrants are by another segment of the same law forbidden movement across the nation's borders. Besides, a clear understanding of the demographic constituents of migrant population involved in Africa-Europe migration and critical information about their cross-border ordeals will expose how all categories of subjects are labeled together and subsumed under one title: "Boat people" or "clandestine" at the receiving societies, which also permits of no distinction in terms of how vulnerable individuals such as minors (children), women and migrants with disabili- 
ties are subjected to policy restrictions at the border. Finally, indications are that most of the attention paid to the victims of contemporary migration and border restriction policies are narrowly focused on female and children. But overlooking the various subcategories of individuals constituting the migrant population invisibilizes the excluded bodies; minimizes the rationality and forecloses the possibility of modifying existing policies to improve their migration experiences. It is crucial to point out that as attention is devoted to fighting human trafficking in current transnational migration, especially as it affects human flow from the developing South to the industrialized North, scholars should endeavor to sift through the mesh formed by a large number of indigent but desperate voluntary migrants who must arrive at their destinations; and the unfounded media speculations about existing trafficking syndicates lurking to prey on passive individuals. This implies that an understanding of the thought process of intending migrants and their determination to reach their goals at all cost might bring about a shift in the view of transnational migration stakeholders and scholars, and possibly chart a new trajectory, which may imply modification of existing policies for accommodation and effective handling of the globally burgeoning cases of irregular migration.

\section{References}

Adepoju, A. (1993). Introduction. In A. Adepoju (Ed.), The Impact of Structural Adjustment on the Population of Africa. New Hampshire: Heinemann.

Anderson, B., Sharma, N., \& Wright, C. (2009). Why No Borders? Refuge, $26,5$. https://www.compas.ox.ac.uk/fileadmin/files/People/staff_publications/Anderson/Refuge26-2-Why-No-Borders.pdf

Appadurai, A. (1996). Modernity at Large: Cultural Dimension of Globalization. New York: University of Minnesota Press.

Applebaum, B. (2005). In the Name of Morality: Moral Responsibility, Whiteness and Social Justice Education. Journal of Moral Education, 34, 277-290. http://dx.doi.org/10.1080/03057240500206089

Araujo, M. (2014). Challenging Mainstream Narratives on Diversity and Immigration in Portugal: Accounting for the History of Colonialism and Racism. In P. Kretsedemas, J. Capetillo-Ponce, \& G. Jacobs (Eds.), Migrant Marginality: A Transnational Perspective. New York; Routledge, Taylor \& Francis Group.

Baxter, J. (2008). Dust from Our Eyes: An Unblinkered Look at Africa. Hamilton: Wolsak and Wynn Publishers.

Belsey, C. (2002). Poststructuralism: A Very Short Introduction. New York: Oxford University Press. http://dx.doi.org/10.1093/actrade/9780192801807.001.0001

Bigo, D. (2005). The Legal Framework: Who Is Entitled to Move? In D. Bigo, \& E. Guild (Eds.), Controlling Frontiers: Free Movement into and within Europe. England: Ashgate Publishing Limited.

Brachet, J. (2012). From One Stage to the Next: Transit and Transport in (Trans) Saharan Migrations. In M. Berriane \& H. de Haas (Eds.), African Migrations Research: Innovative Methods and Methodologies. New Jersey: Africa World Press.

Brown, W. (1993). Wounded Attachments. Political Theory, 21, 390-410. http://dx.doi.org/10.1177/0090591793021003003

Browne, S. A. (2007). Trusted Travelers: The Identity-Industrial Complex, Race and Canada's Permanent Resident Card. Doctor of Philosophy Thesis, Toronto: Department of Sociology and Equity Studies in Education, OISE, University of Toronto.

Chomsky, N. (2006). Failed States: The Abuse of Power and Assault on Democracy. New York: Henry Holt Books.

Chua, A. (2003). World on Fire: How Exporting Free-Market Democracy Breeds Ethnic Hatred \& Global Instability. New York: Doubleday Publishing.

Davies, B. (2006). Subjectification: The Relevance of Butler's Analysis for Education. British Journal of Sociology of Education, 27, 425-438. http://dx.doi.org/10.1080/01425690600802907

Davies, N. (1995). Trial of the Crew Who Murdered Stowaways. The Guardian, November Edition. http://www.nickdavies.net/1995/11/01/trial-of-the-crew-who-murdered-stowaways/

Dei, S. (2011). Introduction. In G. Sefa Dei (Ed.), Indigenous Philosophies and Critical Education: A Reader. New York: Peter Lang.

DeLaet, D. L. (1999). Introduction: The Invisibility of Women in Scholarship of International Migration. In G. A. Kelson, \& D. L. De Laet (Eds.), Gender and Migration. London: Macmillan Press Ltd.

Falola, T., \& Afolabi, N. (2007). Introduction: Migration Fantasies, Nightmarish Realities. In T. Falola, \& N. Afolabi (Eds.), The Human Cost of African Migrations. New York: Routledge.

Fanon, F. (1952). Black Skin, White Masks. New York: Grove Press.

Frenzen, N. (2014). Shifting Responsibilities, EU FRONTEX and Migrant Rights Violation. Migrants at Sea. http://migrantsatsea.org/2014/03/24/interview-with-frontex-director-laitinen/ 
Goldin, I., Cameron, G., \& Balarajan, M. (2011). Exceptional People: How Migration Shaped Our World and Will Define Our Future. Princeton, NJ: Princeton University Press.

Gould, C. (2011). The Problem of Trafficking. In I. Palmary, E. Burman, K. Chantler, \& P. Kiguwa (Eds.), Gender and Migration: Feminist Interventions. London \& New York: Zed Books.

Guild, E. (2009). Criminalization of Migration in Europe: Human Rights Implications. Paris: Commissioner for Human Rights, Council of Europe.

Heller, C., Pezzani, L., \& Studio, S. (2012). The “Left-to-Die Boat” Forensic Oceanography Report. The European Research Council Project. Forensic Architecture Centre for Research Architecture, Goldsmiths, University of London. http://www.fidh.org/IMG/pdf/fo-report.pdf

Immigration and Refugee Board of Canada (2010). Interpreters Training Manual, p. 7.

International Convention for the Safety of Life at Sea (1974). Entry into Force Generally: 1980. Entry into force for Australia: 1983. Australian Treaty Series 1983 No. 22. Australian Government Publishing Service Canberra. Commonwealth of Australia 1995. http://www.austlii.edu.au/au/other/dfat/treaties/1983/22.html

Kelson, G. A. (1999). Conclusion: Policy Considerations for the Twenty-First Century. In G. A. Kelson, \& D. L. DeLaet (Eds.), Gender and Migration. London: Macmillan Press Ltd.

Kimon, B. (2009). Migration through the Eyes of Young People Panel on the Occasion of International Migrants’ Day. New York: United Nations Institute for Training and Research (UNITAR) United Nations Headquarters.

Lebakeng, T. (2010). Discourse on Indigenous Knowledge Systems, Sustainable Socio-Economic Development and the Challenge of the Academy in Africa. CODESRIA Bulletin, Nos. 1 \& 2, p. 24.

Li, P. (2003). Destination Canada: Immigration Debates and Issues. Toronto: Oxford University Press.

Moses, J. W. (2006). International Migration: Globalization’s Last Frontier. London: Zed Books.

Newland, K. (2003). Troubled Waters: Rescue of Asylum Seekers and Refugees at Sea. Migration Information Source. Washington DC: Migration Policy Institute. http://www.migrationpolicy.org/article/troubled-waters-rescue-asylum-seekers-and-refugees-sea

Ngai, M. M. (2005). Impossible Subjects: Illegal Aliens and the Making of Modern America. Oxford: Princeton University Press.

Nwalutu, M. O. (2014). Youth and the 21st Century South-North Migration: In Search of a More Relevant Perspective on Causes, Trend and Flow. Sociology Mind, 4, 1-14. http://dx.doi.org/10.4236/sm.2014.41001

Nyers, P. (2010). No One Is Illegal between City and Nation. Studies in Social Justice, 4, 127-143.

Phillips, M. (2014). Guest Post: The Effect of Negative Labelling-Why Are We Still Talking about “Migrants”? Migrants at Sea.

http://migrantsatsea.org/2014/07/01/guest-post-the-effect-of-negative-labelling-why-are-we-still-talking-about-migrants/

Pisani, M. (2012). Lifelong Learning and Inclusion: The “Citizenship Assumption” and the Exclusion of 8 Million Bodies. 44th EUCEN November Conference "Border-Crossing as a Viable Choice: Collaboration, Dialogue and Access to Higher Education".

Rosenberg, S. (2004). An Introduction to Feminist Poststructural Theorizing. In N. Mandell (Ed.), Feminist Issues: Race, Class and Sexuality. (4th ed., pp. 35-57). Toronto: Pearson/Prentice Hall.

Sassen, S. (1988). The Mobility of Labor and Capital: A Study in International Investment and Labor Flow. Cambridge: Cambridge University Press. http://dx.doi.org/10.1017/CBO9780511598296

Scott, J. (1991). The Evidence of Experience. Critical Inquiry, 17, 773-797. http://dx.doi.org/10.1086/448612

Sefa Dei, G. (2011). Partial Lecture Notes for SES 1921y: "Principles of Anti-Racism” Course. Toronto: OISE University of Toronto.

Sharma, N. (2005a). Canadian Nationalism and the Making of a Global Apartheid. Women \& Environments International Magazine, 68/69, ProQuest p. 9.

Sharma, N. (2005b). Anti-Trafficking Rhetoric and the Making of a Global Apartheid. NWSA Journal, 17, 88-111. http://muse.jhu.edu/journals/ff/summary/v017/17.3sharma.html http://dx.doi.org/10.2979/NWS.2005.17.3.88

Shea, A. (2012). Perilous Territory: Non-Status People in Canada. Oxford Monitor of Forced Migration, 2, 91-105. http://oxmofm.com/wp-content/uploads/2012/06/Perilous-Territory.pdf

Simms, A. (2009). Ecological Debt: Global Warming \& the Wealth of Nations. New York: Pluto Press.

Strik, T. (2012). Lives Lost in the Mediterranean Sea: Who Is Responsible? Report, Committee on Migration, Refugees and Displaced Persons Netherlands, Socialist Group, Council of Europe. 
http://assembly.coe.int/committeedocs/2012/20120329_mig_rpt.en.pdf

Sunderland, J. (2012). Hidden Emergency: Migrants Death in the Mediterranean. Human Rights in Europe. New York: Human Rights Watch. http://www.hrw.org/sites/default/files/related_material/2012_EU_Hidden\%20Emergency.pdf

Toasije, A. (2009). The Africanity of Spain: Identity and Problematization. Journal of Black Studies, 39, 348-355.

http://jbs.sagepub.com/content/39/3/348.full.pdf+html http://dx.doi.org/10.1177/0021934706297563

Valiani, S. (2012). Rethinking Unequal Exchange: The Global Integration of Nursing Labour Markets. Toronto: University of Toronto Press.

WaThiong'O, N. (1986). Decolonizing the Mind: The Politics of Language in African Literature. Nairobi: Educational Publishers.

Wane, N. (2007). Practicing African Spirituality: Insights from Zulu-Latifa, and African Woman Healer. Theorizing Empowerment: Canadian Perspective on Black Feminist Thought (pp. 55-74).

Willinsky, J. (1998). Learning to Divide the World: Education at Empire's End. Minneapolis, MN: University of Minnesota Press. 
Scientific Research Publishing (SCIRP) is one of the largest Open Access journal publishers. It is currently publishing more than 200 open access, online, peer-reviewed journals covering a wide range of academic disciplines. SCIRP serves the worldwide academic communities and contributes to the progress and application of science with its publication.

Other selected journals from SCIRP are listed as below. Submit your manuscript to us via either submit@scirp.org or Online Submission Portal.
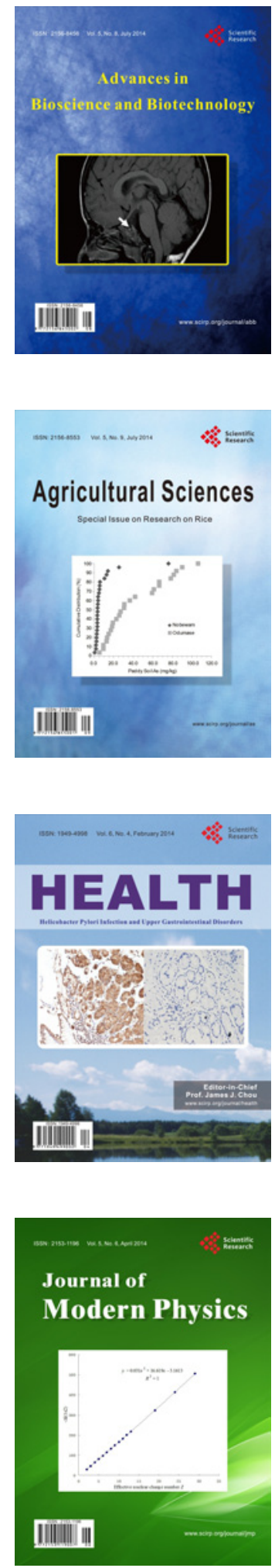
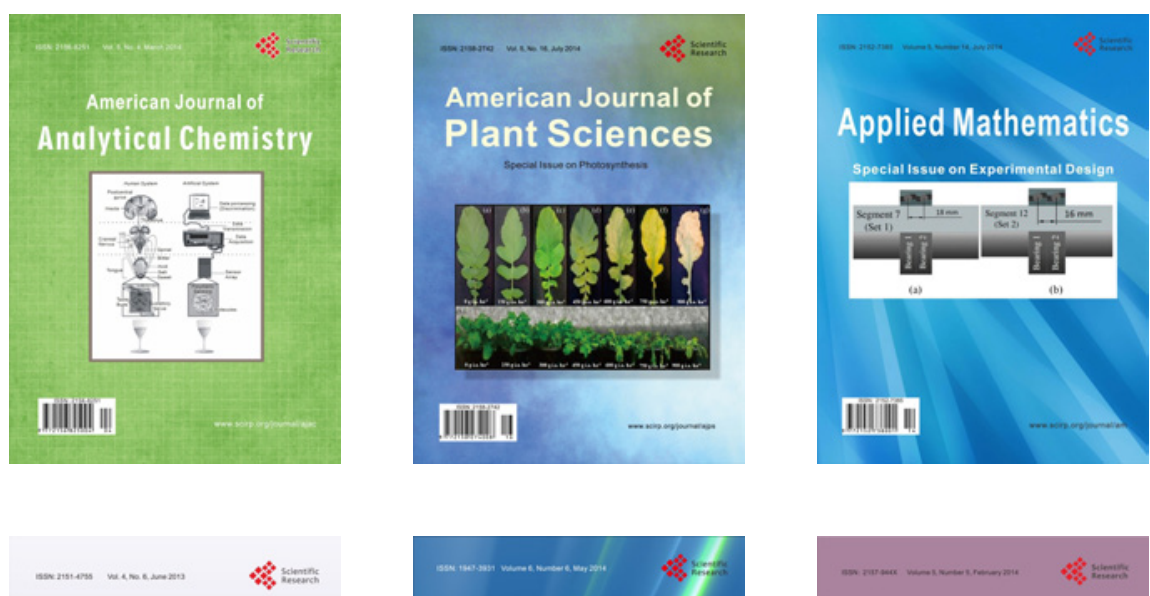

Creative Education
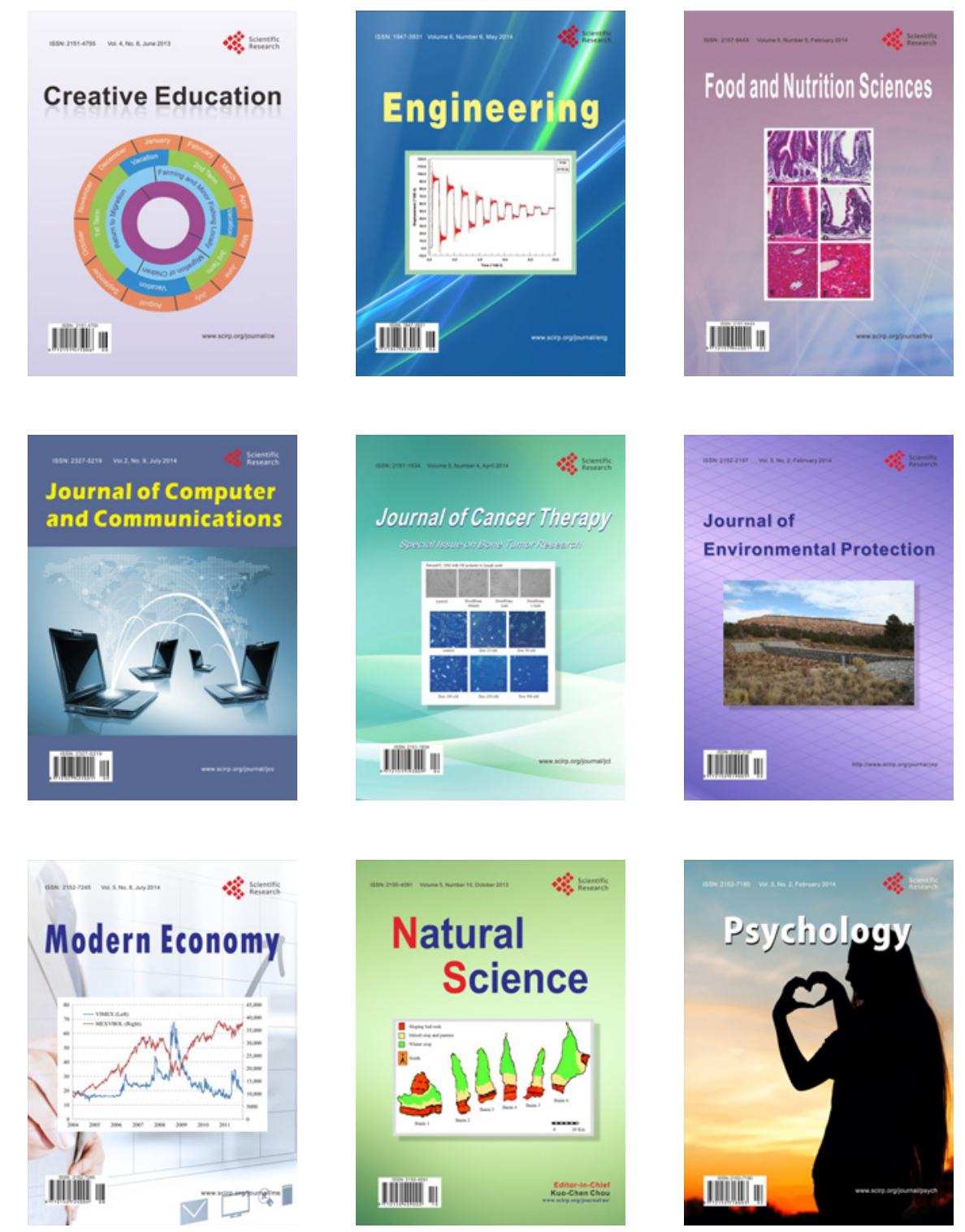